\title{
Taxonomic notes, distribution, and conservation status of two species of Asteraceae firstly recorded for Colombia
}

\author{
Antoni Buira ${ }^{1, *}$, Carlos A. Velasco ${ }^{2} \&$ Joel Calvo $^{3}$ \\ ${ }^{1}$ Real Jardín Botánico de Madrid CSIC, Pza. de Murillo n. ${ }^{\circ}$ 2, 28014 Madrid, Spain. \\ ${ }^{2}$ Herbario Universidad del Cauca-CAUP, Cra 2 n. ${ }^{\circ} 1 \mathrm{~A}-25$ Popayán, Colombia. \\ ${ }^{3}$ Instituto de Geografía, Facultad de Ciencias del Mar y Geografía, Pontificia Universidad Católica de Valparaíso, \\ Avda. de Brasil 2241, 2362807 Valparaíso, Chile. \\ *Author for correspondence: abuira@rjb.csic, https://orcid.org/0000-0002-2775-7017 \\ ${ }^{2}$ caavelasco@unicauca.edu.co, https://orcid.org/0000-0002-5090-541X \\ ${ }^{3}$ calvocasas@gmail.com, https://orcid.org/0000-0003-2340-7666
}

\begin{abstract}
As a result of herbarium studies and field work carried out by the signing authors, two Asteraceae species are recorded for the first time in Colombia, i.e., Floscaldasia azorelloides Sklenář \& H.Rob. (tribe Astereae) and Senecio subinvolucratus Cuatrec. (tribe Senecioneae). Taxonomic notes, pictures, conservation status, and distribution maps are provided for both species.
\end{abstract}

Keywords. Compositae, Floscaldasia, Senecio.
Resumen. Como resultado de la revisión de material de herbario y del trabajo de campo llevado a cabo por los autores, se citan por primera vez en Colombia dos especies de Asteraceae, i.e., Floscaldasia azorelloides Sklenář \& H.Rob. (tribu Astereae) y Senecio subinvolucratus Cuatrec. (tribu Senecioneae). Se presentan además notas taxonómicas, imágenes, estatus de conservación y mapas de distribución de ambas.

Palabras clave. Compositae, Floscaldasia, Senecio.

Buira A., Velasco C.A. \& Calvo J. 2018. Taxonomic notes, distribution, and conservation status of two species of Asteraceae firstly recorded for Colombia. Anales del Jardín Botánico de Madrid 75 (2): e074. https://doi.org/10.3989/ajbm.2514.

Title in Spanish: Notas taxonómicas, distribución y estatus de conservación de dos especies de Asteraceae citadas por primera vez en Colombia.

Received: 4-IX-2018; accepted: 30-X-2018; published online: 28-XI-2018; Associate Editor: C. Aedo.

\section{INTRODUCTION}

The Asteraceae Bercht. \& J.Presl is the second largest family of the Colombian flora, consisting of c. 1,303 species represented by 258 genera (Ávila \& al. 2018). It is one of the most important plant groups in the páramo and the montane forest ecosystems, becoming the most diverse family along the altitudinal gradient of 3000-5000 $\mathrm{m}$ a.s.1. (Bernal 2016).

Herein, we record two new species of Asteraceae for the Colombian flora belonging to the tribes Astereae Cass. and Senecioneae Cass.: Floscaldasia azorelloides Sklenáŕ \& H.Rob. and Senecio subinvolucratus Cuatrec. respectively. Both were considered hitherto endemic to Ecuador. These new findings were possible due to collection trips carried out by the authors, which highlights the importance of the field work, and the revision of herbarium specimens. Taxonomic notes, pictures, conservation status, and distribution maps are provided for both species.

\section{MATERIAL AND METHODS}

This contribution is the result of an intensive review of the published bibliography, and the revision of specimens kept at CAUP, COL, QAP, QCA, and QCNE. Furthermore, photographs of specimens from other institutions were studied: F, MO, UDBC, and US; herbarium acronyms follow Thiers (2018). The conservation status of both species - considered endemic to Ecuador- was reassessed following the IUCN methodology, according to IUCN Red List Categories and Criteria, version 3.1 (IUCN 2001). Distribution maps were prepared using QGIS version 3.0.1 (QGIS Development Team 2018), and geographical coordinates were obtained from herbarium specimens.

\section{RESULTS AND DISCUSSION}

Floscaldasia azorelloides Sklenář \& H.Rob., Novon 10 (2): 146 (2000). Type: Ecuador, Chimborazo/ Morona Santiago, cerros Yuibug-Pailacajas, $1^{\circ} 45^{\prime} \mathrm{S}$ $78^{\circ} 27^{\prime}$ W, 4400 m a.s.1., 31-VII-1997, P. Sklenář and $V$. Sklenárová 2950 leg. (holo-: QCA image!; iso-: AAU n.v., MO image!, PRC n.v., QCNE n.v., US image!).

Tiny rosettiform perennial herb with ramified creeping rhizomes. It is well characterized by its 3-lobed leaves, the solitary terminal capitula, which are subsessile in bloom 
and become long pedunculate as time passes, and the smooth bristles of the pappus (fig. 1).

Distribution and habitat.-In Ecuador it is known from four Andean localities in the northern half of the country - Sara-Urco, YuibugPailacajas, Hermoso and El Altar mounts-, where it forms loose mats in shallow, wet, and sandy substrata on both metamorphic and igneous bedrock of the upper superpáramo - sensu Cleef (1978)—, between elevations of 4200-4500 m a.s.l. (Sklenář \& Robinson 2000). The new Colombian locality was found in the summit of the Sotará Volcano - Cauca Department, southern Central Andes-, about $300 \mathrm{~km}$ away from the northernmost Ecuadorian known population (fig. 2). The species was found thriving in moist sandy soils around igneous rocks, with sparse surrounding vegetation dominated by Calamagrostis sp., Halenia elata Wedd., Hypochaeris sessiliflora Kunth, Phlegmariurus cf. rufescens (Hook.) B.Øllg., Xenophyllum humile (Kunth) V.A.Funk, and Xenophyllum sotarense (Hieron.) V.A.Funk.

Conservation status. - It was catalogued as 'Vulnerable D2' (Barriga \& al. 2011) due to its low number of known locations. This new Colombian locality, besides a recent collection in Central Ecuador -P. Sklenár 13145 leg., QCA-, has considerably increased the extent of occurrence and the number of known populations. While it is still a rare species, it does not meet the criteria to be considered as 'Vulnerable', since the number of known locations is over five. Consequently, Floscaldasia azorelloides is qualified as 'Near Threatened'.

Remarks.-The 3-lobed leaves are very useful to distinguish this species from the other members of the genus, i.e., Floscaldasia hypsophila
Cuatrec. The genus Floscaldasia Cuatrec. is strictly endemic to the páramo and consists of only two species that thrive in Colombia and Ecuador.

Additional specimens examined.-COLOMBIA. Cauca: Sotará, cima del volcán Sotará, $2^{\circ} 06^{\prime} \mathrm{N} 76^{\circ} 35^{\prime} \mathrm{W}, 4440$ m a.s.1., 30-XI-2017, A. Buira, J. Calvo and C.A. Velasco 7638 leg. (CAUP, MA 923838).

ECUADOR. Chimborazo: El Altar, N side of the volcano, $1^{\circ} 41^{\prime} \mathrm{S}$ 78²4' W, 4400 m a.s.1., 19 Aug 1995, P. Sklenár and V. Kostečková 9313 leg. (QCA). Pichincha/Napo: Mountain ridge to the west from Cerro SaraUrcu, 006'S 7758'W, $4350 \mathrm{~m}$ a.s.1., 30-VIII-1995, P. Sklenár and V. Kostečková 1179 leg. (QCA); W side of a mountain ridge c. $2 \mathrm{~km}$ to the west Cerro SaraUrcu, 006' S 77058' W, 4400 m, a.s.1., 29-VIII-1995, P. Sklenář and V. Kostečková 102-108 leg. (QCA). Tungurahua: P.N.N. Llanganates, summit ridge on the SW side of Cerro Hermoso, $1^{\circ} 13^{\prime} \mathrm{S}$ $78^{\circ} 17^{\prime}$ W, 4430 m a.s.1., 4-XII-2010, P. Sklenár 13145 leg. (QCA).

Senecio subinvolucratus Cuatrec., Feddes Repert. Spec. Nov. Regni Veg. 55: 149 (1953); Aetheolaena subinvolucrata (Cuatrec.) B.Nord., Opera Bot. 44: 56 (1978); Lasiocephalus subinvolucratus (Cuatrec.) Cuatrec., Phytologia 40: 312 (1978). Type: Ecuador, Pichincha, Quito, 23-VIII-1920, E.W.D. Holway and M.M. Holway 938 leg. (holo-: US image!).
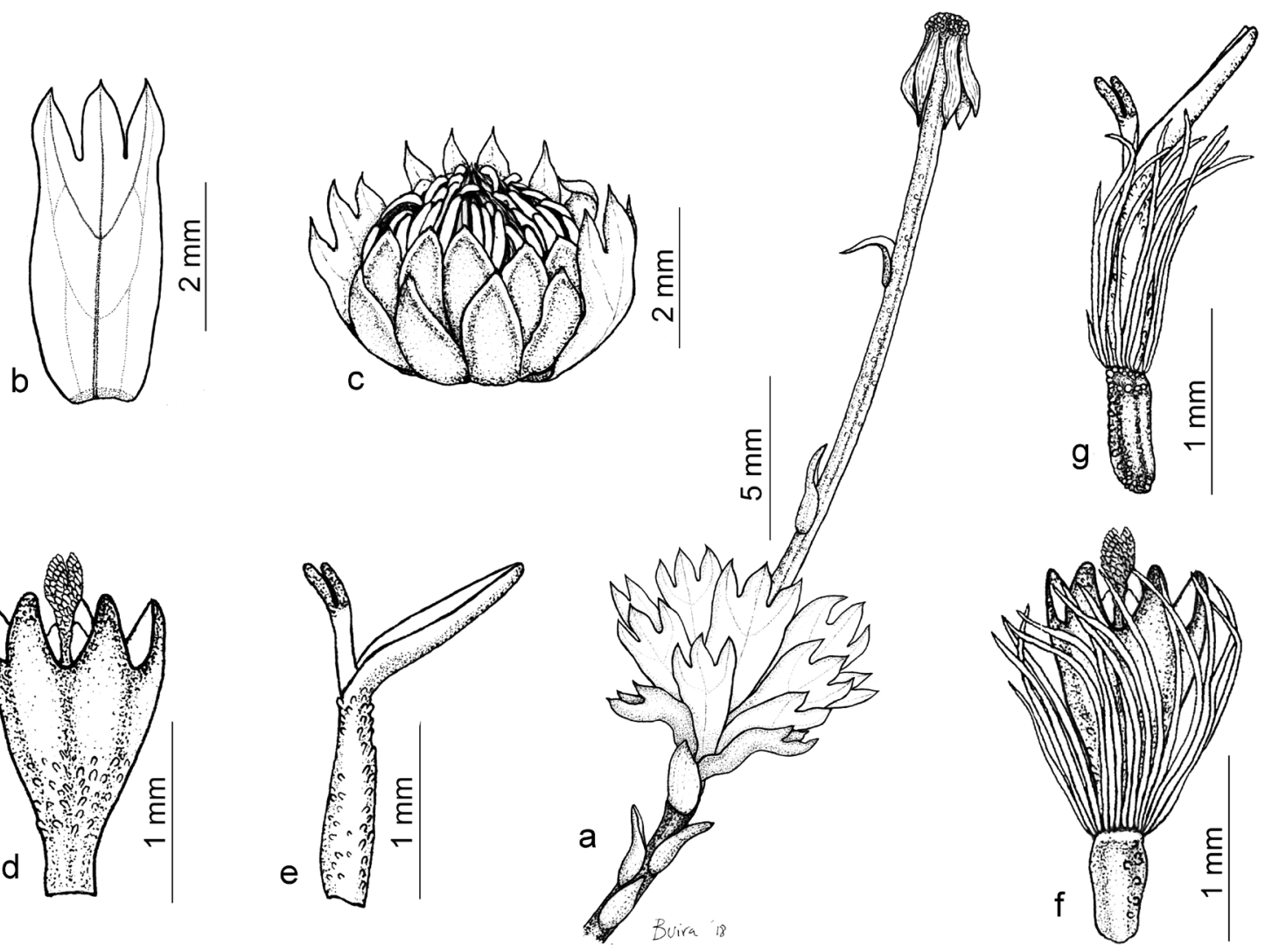

Fig. 1. Floscaldasia azorelloides Sklenář \& H.Rob.: a, rosette and receptacle after the seed dispersal; b, leaf; c, capitulum with some leaves; d, disc floret without ovary and pappus; e, ray floret without ovary and pappus; f, disc floret; g, ray floret. [A. Buira, J. Calvo and C.A. Velasco 7638 leg. (MA 923838); drawing by A. Buira.] 


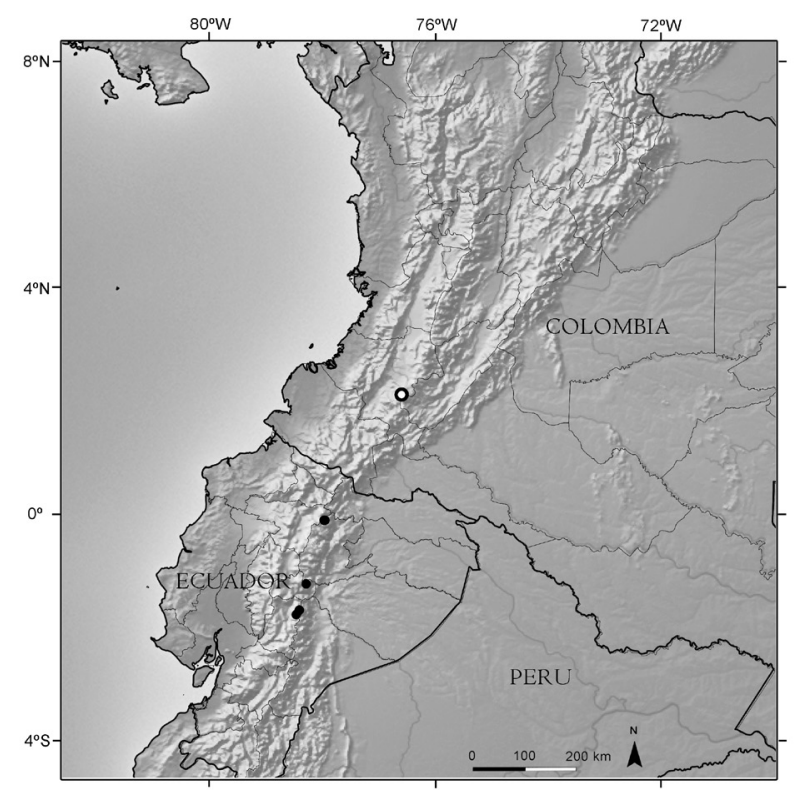

Fig. 2. Distribution map of Floscaldasia azorelloides Sklenáŕ \& H.Rob. [open dot, new record; closed dots, previous records].

Scandent subshrub characterized by displaying discoid, homogamous, nodding capitula, supplementary bracts at the base of the involucre as a calyculus, and penicillate style branches. It has c. 13 involucral bracts and supplementary bracts usually not adpressed to the capitulum and very conspicuous (fig. 3).

Distribution and habitat.-Senecio subinvolucratus occurs from Cotopaxi -northern Ecuadorian Andes - to Puracé - southern Colombian Andes-, growing from the montane forest to the páramo - sensu Cleef 1978), between elevations of 3200-4550 m a.s.1. It has to be noted that the distribution map (fig. 4) of Senecio subinvolucratus provided in this work is not exhaustive and further Colombian herbarium material should be

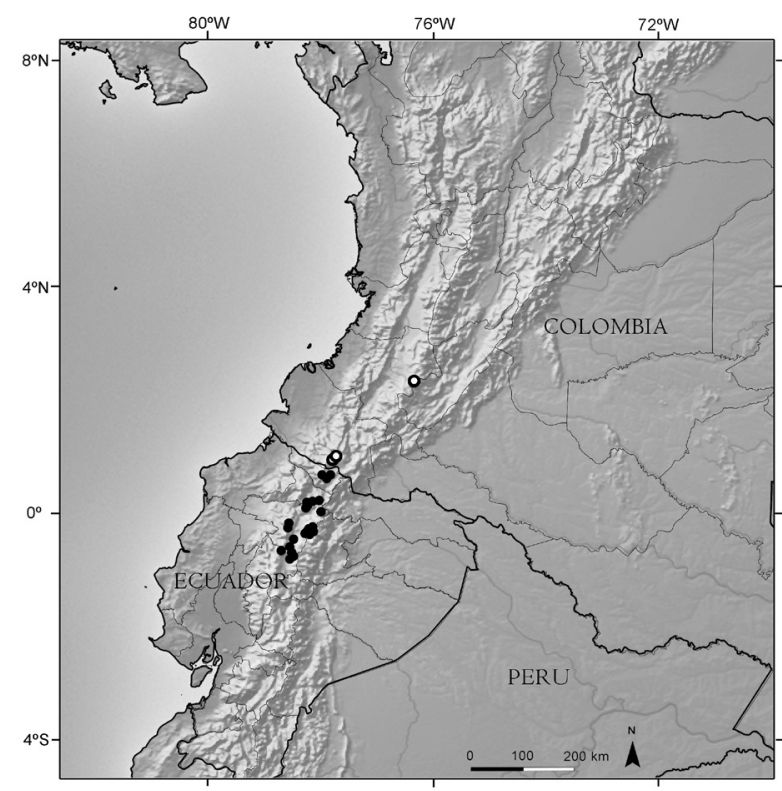

Fig. 4. Distribution map of Senecio subinvolucratus Cuatrec. [open dot, new record; closed dots, previous records].

revised in order to accurately delimit its distribution area — see Remarks section below.

Conservation status.-It was catalogued as 'Endangered B1ab(iii)' -Barriga (2011); sub Aetheolaena subinvolucrata - since only two collections were considered when it was evaluated. Both the current extent of occurrence and the number of known localities show that it is a widespread species and should be treated as 'Least Concern'.

Remarks.-This species, which belongs to the informal 'Senecio group Lasiocephalus' (Calvo \& Freire 2016), is morphologically close to Senecio patens (Kunth) DC. Indeed, it has been frequently misidentified as the latter species. They can be basically differentiated by the shape and arrangement of the supplementary bracts. Senecio subinvolucratus displays lanceolate to broadly lanceolate supplementary bracts, clearly
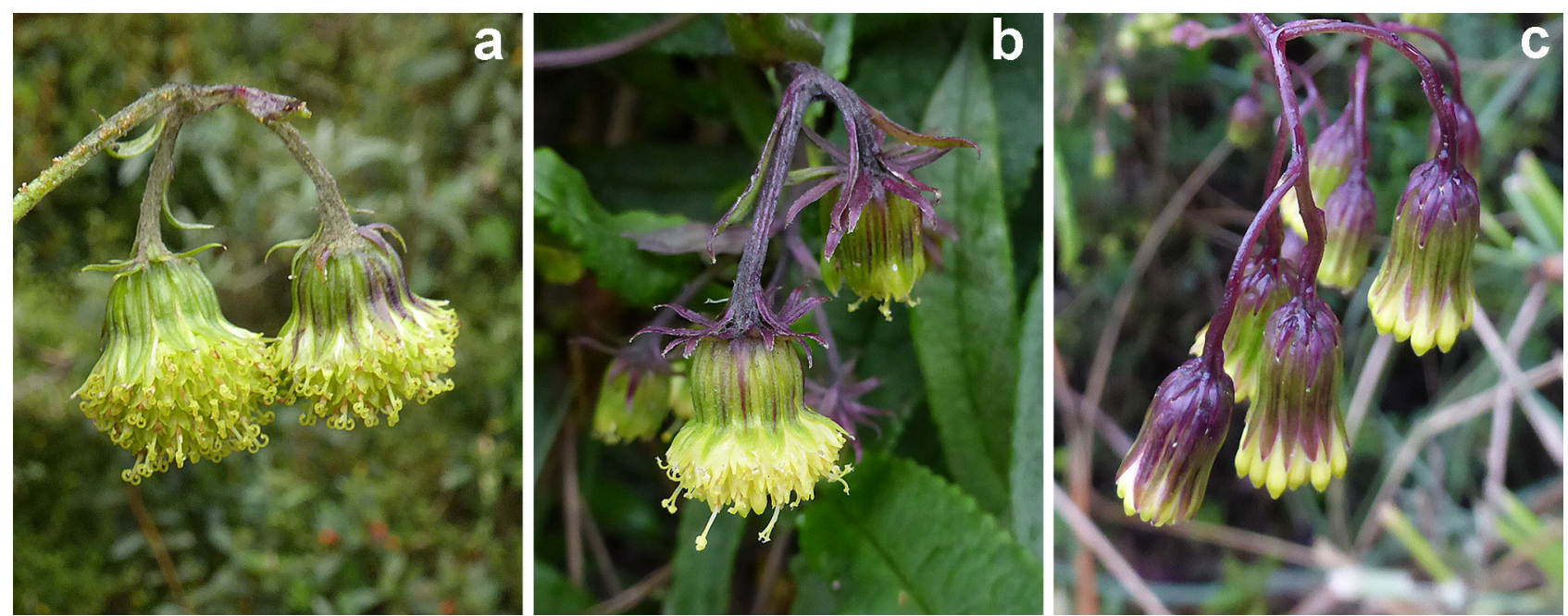

Fig. 3. Discussed species of Senecio L.: a, b, S. subinvolucratus Cuatrec.; c, S. patens (Kunth) DC. [a, Cauca, southern Colombia, J. Calvo 7669 leg. (CAUP); b, c, Carchi, northern Ecuador; photographs by J. Calvo.] 
patent or even slightly reflexed —not adpressed to the capitulum-, and arising from the same level at the base of the capitulum (fig. 3). In contrast, the supplementary bracts of Senecio patens are narrower, almost linear, usually adpressed to the capitulum or almost so, and arising from different levels at the base of the capitulum. This latter feature makes that the supplementary bracts of Senecio patens seem imbricate or multiseriate, and therefore, it is usually difficult to differentiate between the supplementary bracts and the uppermost synflorescence bracts of the pedicel. All the studied specimens of Senecio subinvolucratus have capitula with 13 involucral bracts, while in Senecio patens the number ranges from 11 to 13 . These species are sympatric, which means that a detailed study of the aforementioned characters is required to properly identify them. Until now, Senecio subinvolucratus was only recorded from Ecuador (Salomón \& al. 2018) although Calvo \& Freire (2016) pointed out the possible presence in Colombia on the basis of the Ecuadorian localities near the border. The field work carried out in southern Colombia has enabled us to confirm that Senecio subinvolucratus also occurs in this country. A later revision of some herbarium specimens of this group revealed that Senecio subinvolucratus was already collected in Colombia but misidentified as Senecio patens.

Additional specimens examined.-COLOMBIA. Cauca: Puracé, entrada a la laguna de San Rafael, $02^{\circ} 21^{\prime}$ N 76 $21^{\prime}$ W, 3450 m a.s.l., 7-XII-2017, J. Calvo 7669 leg. (CAUP). Nariño: Túquerres, vereda Amarillo, 13' N $77^{\circ} 46^{\prime}$ W, $3345 \mathrm{~m}$ a.s.l., 23-IV-2009, S. Ángel et al. 267 leg. (UDBC) laguna de Cumbal, $0^{\circ} 56^{\prime} \mathrm{N} 77^{\circ} 48^{\prime} \mathrm{W}, 3500 \mathrm{~m}$ a.s.1., 2-XI-2008, $R$. Cortés and B. Devia 2551 leg. (COL).

ECUADOR. Carchi: $11.4 \mathrm{~km}$ NE of El Ángel on road toward Tulcán, $0^{\circ} 38^{\prime} \mathrm{N} 77^{\circ} 53^{\prime} \mathrm{W}, 3240 \mathrm{~m}$ a.s.1., 13-V-1990, R.M. King et al. $10098 \mathrm{leg}$ (QCNE); Espejo, parroquia La Libertad, reserva ecológica El Ángel, $0^{\circ} 42^{\prime} \mathrm{N} 77^{\circ} 58^{\prime} \mathrm{W}, 3640 \mathrm{~m}$ a.s.1., 10-VIII-2010, J. Brito and F. Anaguano 26 leg. (QAP); El Ángel-Tulcán, vía lagunas El Voladero, km 34, 042'

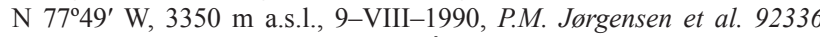
leg. (QCA); Espejo, páramo de El Ángel, $0^{\circ} 40^{\prime} \mathrm{N} 77^{\circ} 50^{\prime} \mathrm{W}, 3400 \mathrm{~m}$ a.s.1., 10-X-1993, D. Neill et al. 10250 leg. (QCNE). Cotopaxi: área de recreación El Boliche, $0^{\circ} 47^{\prime} \mathrm{S} 78^{\circ} 32^{\prime} \mathrm{W}$, C. Cerón and G. Toasa 22698 leg. (QAP); N.P. Cotopaxi, $14 \mathrm{~km}$ E along entrance road opposite $\mathrm{km} 60$ of Panamerican highway, $0^{\circ} 44^{\prime} \mathrm{S} 78^{\circ} 28^{\prime} \mathrm{W}, 3535 \mathrm{~m}$ a.s.1., 15-V-1982, J.L. Luteyn et al. 8388 leg. (QCA); P.N.N. Cotopaxi, $1 \mathrm{~km}$ antes de la entrada, $0^{\circ} 40^{\prime} \mathrm{S} 78^{\circ} 30^{\prime} \mathrm{W}, 3500 \mathrm{~m}$ a.s.1., 15-V-1982, L. Muñoz 187 leg. (QCA); volcán Iliniza, $0^{\circ} 38^{\prime} \mathrm{S} 78^{\circ} 41^{\prime} \mathrm{W}, 4200 \mathrm{~m}$ a.s.1., 18-X-2006, P. Sklenár 9003 leg. (QCA). Imbabura: Otavalo, sector lagunas de Mojanda, $0^{\circ} 7$ N 78 ${ }^{\circ} 15^{\prime}$ W, $3600 \mathrm{~m}$ a.s.1., 27-VI-2015, C. Cerón and C. Reyes 76471 leg. (QAP); volcán Imbabura, quebrada Rumipamba, $0^{\circ} 14^{\prime} \mathrm{N} 78^{\circ} 8^{\prime} \mathrm{W}$ 20-VIII-1995, C. Cerón et al. 29508 leg. (QAP); volcán Imbabura, 0¹0 N 78 $13^{\prime}$ W, 4000 m a.s.1., 20-VIII-1995, M. Reina and C. Cerón 177 leg. (QAP); Mariano Acosta, $0^{\circ} 15^{\prime} \mathrm{N} 78^{\circ} 1^{\prime} \mathrm{W}, 3500 \mathrm{~m}$ a.s.1., 1-XI-1986, P.M. Jørgensen and J. Jaramillo s.n. leg. (QCA). Napo: reserva ecológica Oyacachi, $0^{\circ} 18^{\prime} \mathrm{S} 78^{\circ} 7^{\prime} \mathrm{W}, 3986 \mathrm{~m}$ a.s.1., 29-IX-2007, K. Romoleroux et al. 4608 leg. (QCA.); Baeza, parroquia Papallacta, laguna Sucus, $0^{\circ} 21^{\prime}$ S $78^{\circ} 11^{\prime} \mathrm{W}, 3600 \mathrm{~m}$ a.s.1., 28-XI-2007, C. Cerón and C. Reyes 61221 leg. (QAP); reserva ecológica Oyacachi, $0^{\circ} 13^{\prime} \mathrm{S} 78^{\circ} 8^{\prime} \mathrm{W}, 3783 \mathrm{~m}$ a.s.1., 16-XII-2008, D. Cárate, K. Romoleroux and L.E. López 44 leg. (QCA). Pichincha: el Inga alto, $0^{\circ} 20^{\prime} \mathrm{S} 78^{\circ} 16^{\prime} \mathrm{W}, 4025 \mathrm{~m}$ a.s.l., 13-I-2010, D. Cárate, S. Duchicela and M. Subia 1223 leg. (QCA); vía TabacundoTocachi-Malchingui, $0^{\circ} 13^{\prime} \mathrm{N} 78^{\circ} 14^{\prime} \mathrm{W}, 3960 \mathrm{~m}$ a.s.l., 24-IV-1999, $J$. Jaramillo, I. Tapia and A. Pérez 21039 leg. (QCA); páramo de la Virgen, $0^{\circ} 20^{\prime} \mathrm{S} 78^{\circ} 13^{\prime} \mathrm{W}, 3650 \mathrm{~m}$ a.s.1., 29-IV-2007, C. Cerón 58636 (QAP); volcán Rumiñahui, 0³4' S 78³2' W, 3800 m a.s.1., 4-IX-1993, C. Cerón et al. 23002 leg. (QAP); Quito, Ruccu Pichincha, $0^{\circ} 9^{\prime} \mathrm{S} 78^{\circ} 33^{\prime} \mathrm{W}, 4450 \mathrm{~m}$ a.s.1., 27-IX-2009, C. Cerón and D. Simba 65850 leg. (QAP); páramo de Guamaní, app. $5 \mathrm{~km} \mathrm{~W}$ of paso de la Virgen, $0^{\circ} 19^{\prime} \mathrm{S} 78^{\circ} 13^{\prime} \mathrm{W}, 3700 \mathrm{~m}$ a.s.1., 19-IV-1984, S. Laegaard et al. 52184 leg. (QCA); Quito, cerro Longüi, $0^{\circ} 14^{\prime} \mathrm{S} 78^{\circ} 34^{\prime} \mathrm{W}, 3200 \mathrm{~m}$ a.s.1., 17-VI-2001, C. Cerón et al. s.n. leg. (QAP); NE of Pasochoa, $0^{\circ} 26^{\prime} \mathrm{S} 78^{\circ} 28^{\prime} \mathrm{W}, 3850 \mathrm{~m}$ a.s.l., 30-VII1980, J. Jaramillo et al. 3175 leg. (QCA); Tabacundo, lagunas Mojanda, $0^{\circ} 7^{\prime} \mathrm{N} 78^{\circ} 16^{\prime} \mathrm{W}, 3800 \mathrm{~m}$ a.s.l., 30-VII-1992, W. Palacios et al. 10191 leg. (QCNE); laguna de Hoyas, páramo de Guamaní, $0^{\circ} 15^{\prime} \mathrm{S} 78^{\circ} 12^{\prime} \mathrm{W}$,
$4050 \mathrm{~m}$ a.s.1., 9-VIII-1987, P.M. Ramsay and P.J. Merrow-Smith 235 leg. (QCNE); páramo de la Virgen, $0^{\circ} 18^{\prime} \mathrm{S} 78^{\circ} 14^{\prime} \mathrm{W}, 3500 \mathrm{~m}$ a.s.1., 12 VIII-2007, C. Cerón 60581 leg. (QAP); N side of nevado Cayambe, $0^{\circ} 3^{\prime}$ N 77059' W, 4300 m a.s.1., 6-VIII-2004, P. Sklenár 8100 leg. (QCA); páramo of Ruccu Pichincha, $0^{\circ} 9^{\prime}$ S $78^{\circ} 33^{\prime}$ W, 4550 m a.s.l., 29-X-2010, P. Sklenár 9313 leg. (QCA); $\mathrm{N}$ side of nevado Cayambe, quebrada Angureai, $0^{\circ} 3^{\prime} \mathrm{N} 77^{\circ} 59^{\prime} \mathrm{W}, 4220 \mathrm{~m}$ a.s.1., 3-XI-2007, P. Sklenár and E. Rejzková 10715 leg. (QCA)

\section{ACKNOWLEDGEMENTS}

We are grateful to the curators of the herbaria mentioned in the text. Special thanks to Bernardo Ramírez - CAUP - for all the provided facilities. Andrés F. Bohórquez-Osorio and Lauren Raz - COLkindly attended our queries. This work has partially been funded by FONDECYT from Chile by means of a postdoctoral fellowship of the last author - project No3170270.

\section{REFERENCES}

Ávila F., Funk V.A., Diazgranados M., Díaz-Piedrahita S. \& Vargas O. 2018. Asteraceae. In Bernal R., Gradstein S.R. \& Celis M. (eds.) Catálogo de plantas y líquenes de Colombia. Instituto de Ciencias Naturales, Universidad Nacional de Colombia, Bogotá. Website: http://catalogoplantasdecolombia.unal.edu.co [accessed 11-IV-2018].

Barriga P., Toasa G. \& Montúfar R. 2011. Asteraceae. In León-Yánez S., Valencia R., Pitman N., Endara L., Ulloa Ulloa C. \& Navarrete H. (eds.), Libro Rojo de las Plantas Endémicas del Ecuador, ed. 2: 139-196. Herbario QCA, Pontificia Universidad Católica del Ecuador, Quito.

Bernal R. 2016. La flora de Colombia en cifras. In Bernal R., Gradstein S.R. \& Celis M. (eds.), Catálogo de plantas y líquenes de Colombia: 115138. Instituto de Ciencias Naturales, Universidad Nacional de Colombia, Bogotá.

Calvo J. \& Freire E. 2016. A nomenclator of Senecio group Lasiocephalus (Compositae, Senecioneae): nomenclatural and taxonomic notes and new typifications. Phytotaxa 260: 116-130. https://doi.org/10.11646/phytotaxa.260.2.2

Cleef A.M. 1978. Characteristics of neotropical páramo vegetation and its subantartic relations. In Troll C. \& Laurer W. (eds.), Geoecological Relations Between the Southern Temperate Zone and the Tropical Mountains. Erdwissenschaftliche Forschung 11: 365-390. Steiner, Wiesbaden.

IUCN 2001. IUCN Red List categories and criteria: Version 3.1. IUCN Species Survival Commission, Gland, Switzerland and Cambridge, UK. Website: https://portals.iucn.org/library/node/7977 [accessed 15-IV2018].

QGIS Development Team 2018. QGIS Geographic Information System. Open Source Geospatial Foundation Project. Website: https://www.qgis.org/ [accessed 11-IV-2018].

Salomón L., Sklenář P. \& Freire S.E. 2018. Synopsis of Senecio series Culcitium (Asteraceae: Senecioneae, Senecioninae) in the Andean region of South America. Phytotaxa 340: 1-47. https://doi.org/10.11646/phytotaxa.340.1.1

Sklenář P. \& Robinson H. 2000. Two New Species in Oritrophium and Floscaldasia (Asteraceae: Astereae) from the High Andes of Ecuador. Novon 10: 144-148. https://doi.org/10.2307/3393015

Thiers B. 2018. Index Herbariorum: a global directory of public herbaria and associated staff. New York Botanical Garden's Virtual Herbarium. Website: http://sweetgum.nybg.org/science/ih/ [accessed 11-IV-2018]. 